\title{
Dziewictwo rozumiane jako ustawiczna walka dla Pana. Fundamenty biblijne w Liście 22 św. Hieronima do Eustochium
}

Św. Hieronim² napisał List 22 (O zachowaniu dziewictwa - De virginitate servanda) w Rzymie na przełomie 383 i 384 roku oraz zaadresował go do Eustochium, córki św. Pauli, arystokratki rzymskiej. Pismo stanowi rozprawę o chrześcijańskim dziewictwie zachowywanym ze względu na Chrystusa i Królestwo Niebieskie ${ }^{3}$. Jednocześnie jest przedstawieniem i apologią chrześcijańskiego życia monastycznego. Powstało w czasach, w których nie brakowało przeciwników tego rodzaju życia poświęconego Bogu. Wystarczy wspomnieć Helwidiusza krytykującego ascetyzm chrześcijański czy Jowiniana albo Wigilancjusza przedstawiających monastycyzm jako stan bezużyteczny, a niekiedy nawet niebezpieczny, z racji choćby na rzekomą tendencję wśród mnichów i mniszek do zbytniego zamykania się we wspólnotach i izolacji od świata.

Św. Hieronim opiera się w swoim dziele na licznych tekstach Pisma Świętego i ukazuje, że to, co pisze w związku z podjętymi tematami, nie jest zwykłą mądrością ludzką, ale odzwierciedla naukę objawioną. W podobnym stylu są napisane List 31 (drugi do Eustochium), krótki, bo liczący zaledwie trzy rozdziały, tekst, oraz List 108, czyli Pośmiertna mowa pochwalna na cześć

1 Ks. dr hab. Waldemar Turek, profesor na Università Pontificia Salesiana w Rzymie, pracownik Sekretariatu Stanu Stolicy Apostolskiej; e-mail: turek@tiscalinet.it; ORCID: 0000-0002-8126-4125.

2 Zainteresowanych wykazem podstawowych publikacji w języku polskim i w językach obcych, dotyczących życia i dzieł św. Hieronima, odsyłam do: M. Starowieyski, Hieronim ze Strydonu, NSWP, s. 436-447.

3 Zob. B. Degórski, Wstęp, w: Św. Hieronim, Listy do Eustochium. Listy 22, 31, 108, ŹM 33, Kraków 2004, s. 61. 
św. Pauli (trzeci list do Eustochium). Św. Hieronim porusza w tych trzech pismach $^{4}$ wiele zagadnień związanych $\mathrm{z}$ tematem dziewictwa, które pojmuje jako formę ustawicznej duchowej walki dla Pana połączonej z różnego rodzaju ofiarami i wyrzeczeniami. W niniejszym opracowaniu zamierzam przedstawić tę ideę, analizując konkretne fragmenty wspomnianych listów, oparte przede wszystkim na wybranych przez św. Hieronima tekstach biblijnych.

Omówię zatem najpierw cel, jaki sobie postawił św. Hieronim, pisząc List 22. Zajmę się następnie odnośnymi tekstami biblijnymi, próbując odpowiedzieć na pytania dotyczące ich interpretacji, używanego słownictwa, poruszanych zagadnień. Przejdę następnie do konkretnych elementów opisu dziewictwa rozumianego w sensie duchowej walki podejmowanej dla Chrystusa i jej konkretnych elementów. Jeśli się nie mylę, zagadnienie to nie było do tej pory szczegółowo omawiane ${ }^{5}$. W zakończeniu chciałbym zapytać o znaczenie omawianych tekstów św. Hieronima dla współczesnej debaty w odniesieniu do dziewictwa, małżeństwa i życia zakonnego.

\section{Cel Listu 22 św. Hieronima}

Eustochium zajmowała szczególne miejsce wśród niewiast rzymskich, dla których posługiwał duchowo św. Hieronim w Rzymie ${ }^{6}$. Z same-

4 Wspomniany w poprzednim przypisie Wstęp opracowany przez B. Degórskiego (ŹM 33, s. 11-88) stanowi dobre wprowadzenie w kontekst i tematy poruszane w Listach do Eustochium św. Hieronima. W tym samym opracowaniu znajdujemy obszerną bibliografię (ŹM 33, s. 89-108) uwzględniającą wydania i przekłady listów św. Hieronima, opracowania dotyczące bezpośrednio Listów do Eustochium oraz monastycyzmu żeńskiego i życia ascetyczno-mniszego w Rzymie kierowanego przez św. Hieronima. Zob. także: L. Mirri, Donna e verginità nei Padri (Girolamo e Ambrogio), „Studi Francescani” 88 (1991) s. 339-362; L. Mirri, La dolcezza nella lotta. Donne e ascesi secondo Girolamo, Spiritualità occidentale, Magnano 1996.

5 Na temat dziewictwa i wielu innych aspektów z nim związanych w dziełach św. Hieronima mamy kilka publikacji, które uwzględniono w niniejszym opracowaniu: L. Mirri, La vita ascetica femminile in san Girolamo, Roma 1992; C. Steininger, Die ideale christliche Frau: virgo - vidua - nupta. Eine Studie zum Bild der idealen christlichen Frau bei Hieronymus und Pelagiusz, St. Ottilien 1997; N. Adkin, Jerome on virginity. A Commentary on the Libellus de viriginitate servanda (Letter 22), Classical and Medieval Texts. Papers and Monographs 42, Cambridge 2003; J. Kochel, Nauka o czystości i dziewictwie w Listach św. Hieronima, w: J. Kochel, Wychowanie do czystości - utopia czy zadanie, Człowiek Rodzina - Społeczeństwo 20, Opole 2011, s. 21-35.

6 Zob. J. Gribomont, Eustochio, NDPAC I 1866-1867. Autor syntetycznego opracowania podkreśla, że św. Hieronim zadedykował właśnie Eustochium sporo ze swoich pism, a ona sama brała czynny udział w pracy literackiej swojego mistrza. 
go bowiem Listu 22 wynika, że była ona pierwszą rzymianką z wysokich warstw społecznych, która wybrała dziewictwo jako drogę naśladowania Chrystusa: „Zganiwszy więc i wytępiwszy te, które nie chcą być dziewicami, lecz chcą uchodzić za takie, cała moja mowa zwraca się teraz ku tobie, która jako pierwsza szlachcianka miasta Rzymu zaczęłaś być dziewicą"7.

Do tej właśnie niewiasty św. Hieronim kieruje swój obszerny list i zaraz na początku jasno precyzuje jego cel:

Nie zamierzam teraz głosić pochwał dziewictwa, którego ty wspaniale doświadczyłaś, przeżywając je. Nie chcę także wymieniać przykrości związanych z małżeństwem: jak nabrzmiewa łono, płacze dziecko, dokucza rywalka, przynagla troska o dom i jak wszystko, co uważa się za wartościowe, przerywa ostatecznie śmierć. [...] Nie ma w tym dziełku żadnego pochlebstwa, gdyż pochlebca jest nieprzyjacielem, który schlebia. Nie będzie w nim żadnego przepychu krasomówczych słów, które już stawiałyby ciebie wśród aniołów i, ukazując piękne dziewictwo, rzucały świat pod twoje nogi ${ }^{8}$.

Św. Hieronim wyraźnie odrzuca niektóre cele, których mogliby spodziewać się najpierw Eustochium, a następnie ewentualni inni czytelnicy pisma. Po pierwsze, list nie jest pochwałą dziewictwa (non me nunc laudem virginitatis esse dicturum), które w gruncie rzeczy stało się już udziałem głównej adresatki pisma i która z pewnością rozumie jego sens i jego doniosłość (quam probasti optimam, et consecuta est). Autor zdaje sobie sprawę z tego, że pisze do osoby, która zaznała już smaku i trudów życia w dziewictwie i że do podjęcia takiego stylu życia nie trzeba jej przekonywać. Już na podstawie tego stwierdzenia można domniemać, że jego autor nie będzie koncentrował się na zachęcie do wyboru życia w dziewictwie, ale podejmie jakieś inne tematy z nim związane.

Po drugie, św. Hieronim nie zamierza przedstawiać trosk i zmartwień, jakie niesie ze sobą życie w małżeństwie (nec enumeraturum molestias nuptiarum). Pomija te elementy jako oczywiste i wszystkim dobrze znane. Wystarczy wspomnieć bóle związane z porodem, opiekę na dzieckiem, troskę o rodzinę i dom. Po trzecie, list nie stanowi pochlebstwa w odniesieniu do Eustochium (nulla est enim in hoc libello adulatio), bo ten, kto schlebia, wykazuje niewłaściwą postawę i jest w gruncie rzeczy nieprzyjacielem. Po

\footnotetext{
Hieronymus, Epistula 22, 15.

8 Hieronymus, Epistula 22, 2.
} 
czwarte wreszcie, list nie powstaje w tym celu, aby popisywać się umiejętnościami oratorskimi i krasomówczymi (nulla erit rhetorici pompa sermonis). Św. Hieronim zdawał sobie sprawę ze swoich talentów i umiejętności retorycznych, mógł zatem pokusić się o wychwalanie dziewictwa z punktu widzenia formalnego, posługując się starannie dobranymi słowami, wyszukanymi wyrażeniami, elegancją konstrukcji. Innymi słowy, mógłby się skoncentrować na formie a nie na treści. Jasno jednak odrzuca tego typu możliwość.

Rodzi się zatem niemal spontanicznie pytanie: jaki jest prawdziwy cel Listu 22 św. Hieronima? Wydaje się, że chodzi o to, aby z jednej strony ukazać piękno i sensowność życia w dziewictwie, z drugiej zaś opisać trudy, które trzeba podjąć, aby trwać w dziewictwie, oraz dać pewne rady zwłaszcza osobom, które przyjęły tego typu styl życia, by nie utraciły skarbu dziewictwa. U podstaw tych tematów leży podstawowe założenie, oparte na odnośnych tekstach biblijnych, że życie każdego chrześcijanina, zwłaszcza zaś tego, który otrzymuje szczególne powołanie, jest nieustanną duchową walką:

Dla śmiertelników to życie jest stadionem: tutaj walczymy, aby tam otrzymać wieniec. Nikt nie stąpa bezpiecznie pomiędzy wężami i skorpionami. Pan mówi: „Mój miecz upoił się na niebie” (Iz 34,5), a ty sądzisz, że osiągniesz pokój na ziemi, która rodzi osty i ciernie, którymi karmi się wąż? „Nie toczymy walki przeciw ciału i krwi, lecz przeciw Zwierzchnościom i przeciw Władzom, przeciw rządcom świata tych ciemności, przeciw pierwiastkom duchowym zła na wyżynach niebieskich" (Ef 6,12). Otaczają nas wielkie odziały wrogów, wszystko roi się od wrogów⿳9.

W przytoczonym tekście dostrzegamy dwa teksty biblijne traktowane przez św. Hieronima jako fundamenty ukazywanej przez siebie idei: jeden pochodzi z Księgi Izajasza, drugi zaś - z Listu św. Pawła do Efezjan. Apostoł Narodów w wielu fragmentach swoich pism chętnie używał słów i obrazów

9 Hieronymus, Epistula 22, 3. Zob. B. Degórski, L’insegnamento monastico Geronimiano, VoxP 32-33 (1997) s. 199-214. Autor opracowania analizuje niektóre inne teksty św. Hieronima ukazujące każdego chrześcijanina, zwłaszcza zakonnika, jako żołnierza Chrystusa: „Ogni cristiano e in particolare il monaco è un soldato di Cristo e, perciò, deve essere forte e coraggioso, combattendo per lui e dimostrandolo con la vita e non cercando le comodità mondane. Il coraggioso amore per Cristo deve essere persino più grande di quello per i propri genitori o i cari' (Degórski, L'insegnamento monastico Geronimiano, s. 206). 
ukazujących walkę, zachęcając swoich adresatów do tego, aby go naśladowali, podejmowali wyrzeczenia, podobnie jak to czynią atleci, aby wygrać zawody i otrzymać nagrodę: „Czyż nie wiecie, że gdy zawodnicy biegną na stadionie, wszyscy wprawdzie biegną, lecz jeden tylko otrzymuje nagrodę? Przeto tak biegnijcie, abyście ją otrzymali" $(1 \text { Kor } 9,24)^{10}$. Ten i podobne teksty św. Pawła apostoła były niewątpliwie bliskie św. Hieronimowi, który nie ukrywał różnych trudności, na jakie napotykał w swoim życiu chrześcijanin. Co więcej, miał odwagę stwierdzić, że „Otaczają nas wielkie oddziały wrogów, wszystko roi się od wrogów”. Podobnie jest w następnym fragmencie listu św. Hieronima, w którym dostrzega się wpływ myśli Apostoła Narodów:

Jak długo pozostajemy w tym kruchym ciele ${ }^{11}$, jak długo „przechowujemy zaś ten skarb w naczyniach glinianych" ( 2 Kor 4,7$)$, a duch pożąda rzeczy przeciwnych ciału, a ciało przeciwnych duchowi, tak długo nie istnieje żadne pewne zwycięstwo. Nasz przeciwnik - diabeł - rycząc jak lew, krąży, szukając, aby coś pożreć. [...] Diabeł nie szuka ludzi niewiernych, nie szuka tych, którzy są na zewnątrz [...]. Zależy mu, aby wyrwać [ludzi] z Kościoła Chrystusa $^{12}$.

Życie chrześcijanina jest nieustannym zmaganiem się, rzeczywistością dynamiczną, wymagającą ciągłej uwagi - nie można być nigdy pewnym zwycięstwa. W końcowej części przytoczonego tekstu św. Hieronim mówi bezpośrednio o diable, który jest ciągle w poszukiwaniu ofiar. Ten zaś upatruje sobie w sposób szczególny ludzi, którzy są wewnątrz Kościoła i stara się na różne sposoby wyprowadzić ich ze wspólnoty wierzących.

Św. Hieronim, przedstawiwszy koncepcję życia ludzkiego z mocnym podkreśleniem potrzeby ciągłego zmagania się i walki duchowej, proponuje w podobnych kategoriach ideę chrześcijańskiego dziewictwa.

10 Tego typu słownictwo spotykamy u św. Pawła także w znanym tekście 2Tm 4,7-8: „W dobrych zawodach wystąpiłem, bieg ukończyłem, wiary ustrzegłem. Na ostatek odłożono dla mnie wieniec sprawiedliwości, który mi w owym dniu odda Pan, sprawiedliwy Sędzia, a nie tylko mnie, ale i wszystkim, którzy umiłowali pojawienie się Jego”. Gdy chodzi o teksty biblijne innych autorów ukazujących życie chrześcijan jako walkę, można wskazać Jk 1,12; 1P 5,4; Ap 2,10; 3,11; 6,2.

11 W tekście oryginalnym jest tu użyte łacińskie słowo corpusculum, co oznacza dosłownie 'ciałko, ciałko delikatne'. Począwszy od IV wieku było ono używane także na określenie ciała martwego albo ciała ascety. Zob. Hieronymus, Vita S. Pauli Primi Eremitae XI 3.

12 Hieronymus, Epistula 22, 4. 


\section{Niektóre teksty biblijne o dziewictwie w interpretacji św. Hieronima}

Autor wpisuje się w tradycję wcześniejszych pisarzy chrześcijańskich, którzy w sposób klarowny podawali motywację dziedzictwa opartą głównie na argumentach biblijnych. Odwoływali się oni przede wszystkim do postawy i słów samego Zbawiciela zapisanych w Ewangeliach. Podkreślali zatem, że Królestwo Boże jest realizowane w Chrystusie, który prowadził życie bezżenne. Kto uznaje dziewictwo, jest w harmonii z głoszoną przez Jezusa nauką, który mówił: „Nie wszyscy to pojmują, lecz tylko ci, którym to jest dane. Bo są niezdatni do małżeństwa, którzy z łona matki takimi się urodzili; i są niezdatni do małżeństwa, których ludzie takimi uczynili; a są także bezżenni, którzy ze względu na królestwo niebieskie sami zostali bezżenni. Kto może pojąć, niech pojmuje!” (Mt 19,11-12). Echo tych słów dostrzegamy w osobistym stwierdzeniu św. Hieronima: „Przed wielu laty z powodu królestwa niebieskiego odciąłem się od domu, rodziców, siostry, krewnych i - co jest trudniejsze od tego wszystkiego - od lubowania się w wytwornych ucztach, i podążyłem do Jerozolimy, aby walczyć"13.

Św. Hieronim znał doskonale zachętę Jezusa do trwałego i dobrowolnego bezżeństwa tych, którzy chcą się poświęcić wyłącznie Królestwu Bożemu. W rzeczywistości tylko ono jest usprawiedliwieniem dziewictwa chrześcijańskiego i tylko ci, którym jest to dane, mogą zrozumieć te słowa. Te zaś nadają dziewictwu chrześcijańskiemu wymiary eschatologiczne. $\mathrm{Ci}$, co żyją w bezżeństwie, nie są przywiązani do tego świata. Podobnie jak w przypowieści Jezusa o dziesięciu pannach zapisanej w Mt 25,1-13 ludzie ci oczekują na oblubieńca i na Królestwo Niebieskie. To w odniesieniu do tej przypowieści św. Hieronim pisze: „Dziewice głupie, które - nie mając oliwy - nie są dopuszczone do Oblubieńca"14.

Szczególnie ważny dla św. Hieronima był siódmy rozdział Pierwszego Listu św. Pawła Apostoła do Koryntian: „Nie mam zaś nakazu Pańskiego co do dziewic, lecz daję radę jako ten, który - wskutek doznanego od Pana miłosierdzia - godzien jest, aby mu wierzono. Uważam, iż przy obecnych utrapieniach dobrze jest tak zostać, dobrze to dla człowieka tak żyć. Jesteś związany z żoną? Nie usiłuj odłączać się od niej! Jesteś wolny? Nie szukaj żony! Ale jeśli się ożenisz, nie grzeszysz. Podobnie i dziewica, jeśli wychodzi za mąż, nie grzeszy. Tacy jednak cierpieć będą udręki ciała, a ja chciałbym ich wam oszczędzić” (1Kor 7,25-28).

13 Hieronymus, Epistula 22, 30.

14 Hieronymus, Epistula 22, 5. 
W tekście dostrzega się równość w ocenie dziewictwa i małżeństwa ukazaną w słowach: „Jeśli się ożenisz, nie grzeszysz. Podobnie i dziewica, jeśli wychodzi za mąż, nie grzeszy". Następnie jednak apostoł stwierdza w odniesieniu do tych, którzy się żenią albo za mąż wychodzą: „Tacy jednak cierpieć będą udręki ciała, a ja chciałbym ich wam oszczędzić". Św. Hieronim w sposób bardzo konkretny wyjaśnia ten tekst św. Pawła:

„Nie mam zaś nakazu Pańskiego - mówi Apostoł - co do dziewic”. Dlaczego? Ponieważ i on sam był dziewiczym nie na mocy [jakiegoś] rozkazu, lecz z własnej woli. [...] Dlaczego więc nie ma nakazu Pana odnośnie do dziewictwa? Ponieważ ma większą wartość to, co nie jest wymuszone, lecz co jest ofiarowane. Jeśli bowiem dziewictwo byłoby nakazane, małżeństwo wydałoby się być przekreślone. Byłoby ponadto czymś bardzo twardym i wbrew naturze zmuszać ludzi do życia anielskiego i tego od nich wymagać oraz w jakiś sposób potępiać to, co zostało stworzone ${ }^{15}$.

Św. Hieronim, opierając się na nauczaniu św. Pawła apostoła, podkreśla przede wszystkim fakt dziewiczego życia samego Apostoła Narodów i tego, że był to jego wolny wybór. Wydaje się, że stosunkowo mało autorów okresu patrystycznego zwraca uwagę na ten aspekt życia św. Pawła. Pisarz wykorzystuje następnie ten fakt, aby wyraźnie ukazać, że dziewictwo jest kwestią wyboru, a nie nakazu, i jako takie ma większą wartość. Chrześcijanin wybiera dziewictwo, a nie jest do niego zmuszony. Logicznie następnie stwierdza, że jeśli dziewictwo byłoby nakazane, w ten sposób przekreślone byłoby małżeństwo. Małżeństwo jest czymś naturalnym i tylko niektórzy mogą podjąć się życia, które św. Hieronim nazywa życiem anielskim.

Pewne przeciwstawienie dziewictwa małżeństwu nie ma natury filozoficznej, ale dotyczy przejścia od „teraźniejszości” do „przyszłości” w ramach historii zbawienia. Małżeństwo należy bowiem do porządku prowizorycznego, który kiedyś przeminie: „Przy zmartwychwstaniu bowiem nie będą się ani żenić, ani za mąż wychodzić, lecz będą jak aniołowie Boży w niebie" (Mt 22,30) ${ }^{16}$.

15 Hieronymus, Epistula 22, 20.

16 Zob. I. de la Potterie, Dziewictwo, w: Słownik Teologii Biblijnej, red. X. LéonDufour, tł. K. Romaniuk, Poznań - Warszawa 1982, s. 256: „Podobnie jak w przypowieści Jezusa (Mt 25, 1.6) ludzie ci oczekują na Oblubieńca i na królestwo niebieskie. Jak ciągłe objawianie dziewictwa Kościoła życie ich jest także świadectwem nieprzynależenia chrześcijan do tego świata; jest «znakiem» trwałym pewnego napięcia eschatolo- 
Pisarz, opierając się na niektórych tekstach biblijnych, rozróżnia dziewictwo cielesne i dziewictwo duchowe. W odniesieniu do tych osób, które zbytnio troszczą się o swoje ciało i codziennie obliczają dochody z posiadłości, stawia pytanie:

Czy one mogą być dziewicami? „Nie tak bowiem człowiek widzi, jak widzi Bóg, bo człowiek patrzy na twarz, Bóg patrzy na serce" (1 Sm 16,7). Dlatego, jeśli nawet cieleśnie są dziewicami, nie wiem, czy są dziewicami duchem. Tak bowiem określił dziewicę Apostoł: „By była święta i ciałem, i duchem (Ut sit sancta corpore et spiritu)" (1 Kor 7,34) ${ }^{17}$.

Dziewice, które zachowują jedynie dziewictwo cielesne, nie mogą być właściwymi przykładami dla tych, które szukają prawdziwego dziewictwa: w rzeczywistości bowiem zatrzymują one dla siebie chwałę i nawet jeśli powstrzymują się przed współżyciem cielesnym, napawają się różnymi rozkoszami odnoszącymi się do ciała.

To interesujące rozróżnienie między dwoma typami dziewictwa pojawia się także w innym tekście św. Hieronima, w którym stwierdza on, że nawet sam Bóg nie może podnieść dziewicy po upadku:

Powiem zuchwale: chociaż Bóg wszystko może, to jednak nie może podnieść dziewicy po upadku. Mocen jest wyzwolić od kary, lecz nie może uwieńczyć zepsutej. [...] Pan powiada: „Każdy, kto pożądliwie patrzy na kobietę, już się w swoim sercu dopuścił z nią cudzołóstwa" (Mt 5,28). Dziewictwo więc może przepaść także z powodu myśli. To są te złe dziewice: dziewice ciałem, nie duchem; dziewice głupie, które - nie mając oliwy - nie są dopuszczone do Oblubieńca ${ }^{18}$.

Jak wynika z przytoczonych tekstów, wymagania religii chrześcijańskiej w odniesieniu do spraw seksualnych są wyjątkowo surowe: nie chodzi tylko o powstrzymywanie się od współżycia seksualnego, czyli, innymi słowy, nie wystarczy dziewictwo cielesne, ale chodzi o to duchowe, np. w sferze myśli, pragnień i spojrzeń. To ostatnie wymaga szczególnych wyrzeczeń i szczególnej duchowej walki.

gicznego w Kościele; jest antycypacją stanu zmartwychwstania, kiedy to ci, co zostaną uznani za godnych uczestniczenia w świecie przyszłym, będą podobni do aniołów, do synów Bożych”.

17 Hieronymus, Epistula 22, 38.

18 Hieronymus, Epistula 22, 5. 


\section{Dziewictwo jako plaszczyzna duchowej walki przy pomocy darów Bożych}

Niektórzy autorzy starożytnego chrześcijaństwa ukazywali wiernych Chrystusa, zwłaszcza mnichów, jako tych, którzy walczą przeciwko Szatanowi i złu, jak to czynili ich duchowi poprzednicy, czyli męczennicy ${ }^{19}$. Św. Hieronim podejmuje i rozwija tę myśl zwłaszcza w odniesieniu do dziewic:

Wszystko, co przedstawiliśmy, wyda się twardym temu (dura videbuntur), kto nie kocha Chrystusa. Kto zaś uważa wszelki przepych świata za śmieci, a za próżne to wszystko, co jest pod słońcem, aby pozyskać Chrystusa, kto umarł i zmartwychwstał ze swym Panem i ukrzyżował swoje ciało wraz z wadami (vitiis) i pożądliwościami (concupiscentiis), ten swobodnie będzie głosił: „Któż nas odłączy od miłości Chrystusowej? Utrapienie, ucisk czy prześladowanie, głód czy nagość, niebezpieczeństwo czy miecz" (Rz 8,35)? ${ }^{20}$.

Według św. Hieronima trudy związane z życiem w dziewictwie wydają się twarde temu, kto nie kocha Chrystusa. To stwierdzenie jest istotne dla zrozumienia sensu dziewictwa w ujęciu religii chrześcijańskiej, które jest odnoszone do Chrystusa. Autor listu precyzuje następnie, na czym konkretnie ten związek ze Zbawicielem ma polegać. Najpierw zatem trzeba uznać przepych świata za śmieci, co stanowi warunek sine qua non aby pozyskać Chrystusa. Następnie trzeba umrzeć razem z Nim i zmartwychwstać, co sprawia, że człowiek rodzi się na nowo od strony duchowej. Wreszcie trzeba ukrzyżować swoje ciało wraz z pożądliwościami i wadami. Tylko pod tymi warunkami żadna rzeczywistość nie jest w stanie odłączyć chrześcijanina od miłości Chrystusowej. Św. Hieronim przytacza w tym kontekście znany tekst św. Pawła z jego Listu do Rzymian $(8,35)$ ukazujący Jezusa, który sam znosił trudy i rozmaite cierpienia życia ludzkiego:

Syn Boży stał się dla naszego zbawienia synem człowieczym: czeka w łonie przez dziewięć miesięcy, aby się narodzić i znosi przykrości [ciąży], zakrwawiony wydobywa się, owijają Go w pieluszki, uśmiecha się pod wpływem pieszczot. Ciasny żłób obejmuje Tego, w którego dłoni zawiera się świat. Przemilczam, że aż do trzydziestego roku [życia], [pozostając] nieznanym,

19 Zob. na ten temat: A. Bandura, Athleta Christi nella patristica latina dei primi quattro secoli, Roma 1994, s. 47-54.

20 Hieronymus, Epistula 22, 39. 
zadowala się ubóstwem rodziców; biczowany - milczy; krzyżują Go, a modli się za krzyżujących ${ }^{21}$.

Jezus dał nam dowody najwyższej miłości, pokory, skromnego życia, ubóstwa, cierpliwości i wytrwałości w cierpieniu, modlitwy za oprawców. Ta miłość Jezusa zachęca nas, abyśmy w codziennym życiu odpowiadali na nią miłością i konkretnie podejmowanymi walkami, różnymi wyrzeczeniami tak w odniesieniu do ciała, jak i do ducha. Tak było też w przypadku św. Hieronima, który bardzo szczerze i obrazowo opowiada adresatce listu o swoich wyrzeczeniach:

O, ileż razy, przebywając na pustyni i na owym szerokim pustkowiu, które spalone żarem słońca dostarcza mnichom tego okropnego mieszkania, sądziłem, że znajduję się pośród rzymskich rozkoszy! Siedziałem samotny, gdyż byłem przepełniony goryczą. Strasznie wyglądałem z powodu powykrzywianych przez wór pokutny członków. [...] O pokarmach zaś i napoju zamilczę, gdyż nawet chorzy używają [tam] zimnej wody, a przyjmowanie czegoś gotowanego jest zbytkiem. Mnie więc, właśnie mnie, który z powodu strachu przed gehenną skazałem siebie samego na takie więzienie $w$ towarzystwie jedynie skorpionów i dzikich zwierząt, często wydawało się, iż znajduję się wśród tańczących dziewcząt! !2

Św. Hieronim ukazuje właśnie na podstawie swoich osobistych przeżyć, że chrześcijanin jest wszędzie zagrożony przez nieprzyjaciela, a pustynia, umartwienia i posty nie zwalniają go od czuwania i szukania pomocy w łasce Bożej. Postanawia zatem dać pewne wskazówki rozumiane jako reguły mniszego postępowania. Rozpoczyna je od zwrócenia uwagi na szukanie odpowiedniego towarzystwa:

Niech twoimi towarzyszkami będą te, które widzisz, że je wycieńczają posty, które mają blade twarze, które zarówno wiek jak i życie wypróbowało, które codziennie śpiewają w swych sercach: „Gdzie pasiesz swe stada, gdzie dajesz im spocząć w południe” (Pnp 1,7), które mówią z uczuciem: „Pragnę odejść, a być z Chrystusem" (Flp 1,23)

\footnotetext{
21 Hieronymus, Epistula 22, 39.

22 Hieronymus, Epistula 22, 7.

23 Hieronymus, Epistula 22, 17.
} 
W przytoczonym tekście dostrzegamy dwa odniesienia biblijne. Jedno pochodzi z Pieśni nad Pieśniami z możliwą reminiscencją tekstu Rdz 37,15-16: „Gdy [Józef] błąkał się po polu, spotkał go pewien człowiek. Zapytał go więc ów człowiek: «Kogo szukasz?». Odpowiedział: «Szukam moich braci. Powiedz mi, proszę, gdzie oni pasą trzody»”. Jest w tych tekstach nawiązanie do tematu rozłąki i poszukiwania, który pojawia się często w literaturze miłosnej, podobnie jak temat obecności i przynależenia ${ }^{24}$. Chodzi o ważne rzeczywistości, przeżywane, choć w nieco inny sposób, także w życiu dziewicy: ona odczuwa rozłąkę i tęskni za Zbawicielem. Do takiej interpretacji upoważnia nas w jakiejś mierze także drugi cytat biblijny występujący w przytoczonym wyżej tekście św. Hieronima, pochodzący z Listu do Filipian. Św. Paweł wyjaśnia w nim, że pragnie odejść, aby „być z Chrystusem”, co oznacza łączyć w czasie życia ziemskiego nasze cierpienia z cierpieniami samego Zbawiciela.

Druga, praktyczna rada dawana przez św. Hieronima dziewicom, dotyczy pozostawania w domu: „Rzadko wychodź na ulicę; szukaj męczenników w twoim mieszkaniu. Nie brakowałoby nigdy powodu do wyjścia, gdybyś zawsze wychodziła, gdy jest to konieczne"25. Zauważamy w tym tekście nieco zaskakującą zachętę: „,szukaj męczenników w twoim mieszkaniu”. Jeden ze współczesnych znawców życia i dzieł św. Hieronima wyjaśnia:

Eustochium nie powinna wychodzić z domu nawet po to, by uczcić miejsca uświęcone krwią męczenników. Powinna czynić to duchowo, w swoim pokoju. Chęć opuszczenia „klauzury” domowej w celach nabożnych, jakimi był choćby kult męczenników, stanowiła niewątpliwie dla Eustochium dużą ,,pokusę". W czasie bowiem, w którym Hieronim pisze, w Wiecznym Mieście szerzyła się wielce cześć męczenników, a miejsca, na których przelali oni krew dla Chrystusa (względnie ich groby), przyciągały rzesze wiernych ${ }^{26}$.

Już ten przykład i to wyjaśnienie wskazują, że dziewica może opuszczać swoje mieszkanie jedynie dla bardzo poważnego, niemal koniecznego powodu.

Trzecia zachęta dotyczy strony intelektualnej i duchowej dziewicy. Św. Hieronim radzi Eustochium: „Bardzo często czytaj i jak najwięcej się

24 Zob. Biblia Jerozolimska, s. 890: „W Pnp jest wprowadzony w 3,1-4; 4,8; 5,28; 6,1. Ramy stanowi tu idylla pasterska (por. Jakub i Rachela - Rdz 29,1-12). W Pnp 5,2-8 ramy będą odmienne, nie są to już bowiem sytuacje rzeczywiste".

25 Hieronymus, Epistula 22, 17.

26 B. Degórski, Wstęp, s. 135, przyp. 129. 
ucz. Niech zaskakuje cię sen, gdy trzymasz księgę, a opadającą twarz niech podtrzymuje święta strona"27.

Pisarz zachęca dziewice do lektury i nauki. Należy podkreślić owo charakterystyczne wyrażenie ,jak najwięcej”, z którego wynika, że w sprawie nauki nie ma żadnych ograniczeń. Chodzi jednak o szczególną „naukę”, tę opartą na medytacji Pisma Świętego, jak wskazuje wyrażenie „święta strona".

Kolejna rada, dawana przez św. Hieronima, związana jest z koniecznością podejmowania praktyk postnych w życiu dziewicy:

Pość codziennie i unikaj posilania się do syta. Na nic się zda nosić pusty brzuch przez dwa czy trzy dni, jeśli później się go napycha, wynagradzając post jedzeniem w nadmiarze. Umysł z powodu sytości od razu gnuśnieje, a nawodniona ziemia rodzi ciernie pożądliwości. Gdy poczułabyś, że zewnętrzny człowiek (exterior homo) wzdycha za kwiatem młodości i, gdy po przyjęciu pokarmu leżąc w łóżku, napadałoby na ciebie mamidło pożądliwości, chwyć tarczę wiary, na której gaszą się ogniste strzały diabła ${ }^{28}$.

Najpierw zatem mamy zachętę do właściwego, rozumnego i ciągłego poszczenia, jak też do stałej ascezy praktykowanej codziennie w życiu dziewicy. Innymi słowy, nie chodzi o jednorazowe praktyki pokutne, ale o pewien wypracowany styl życia. Dostrzega się następnie w przytoczonym tekście wyraźne nawiązanie do słów św. Pawła o człowieku wewnętrznym i zewnętrznym: „Albowiem wewnętrzny człowiek [we mnie] ma upodobanie zgodne z Prawem Bożym” (Rz 7,22); „Dlatego to nie poddajemy się zwątpieniu, chociaż bowiem niszczeje człowiek zewnętrzny, to jednak ten, który jest wewnątrz, odnawia się z dnia na dzień" $(2$ Kor 4,16$)$. W rozumieniu św. Pawła człowiek wewnętrzny określa rozumną część człowieka, człowiek zewnętrzny natomiast odnosi się do ciała podległego cierpieniu i śmiertelnemu. U św. Hieronima określenie ,zewnętrzny człowiek” odnosi się raczej do warstwy zmysłowej i cielesnej człowieka, która - jeśli nie będzie odpowiednio pielęgnowana - sprzeciwia się warstwie duchowej.

Szczególne znaczenie ma użyty przez św. Hieronima zwrot „chwyć tarczę wiary” nawiązujący znowu do dzieł św. Pawła: „W każdym położeniu bierzcie wiarę jako tarczę, dzięki której zdołacie zgasić wszystkie

27 Hieronymus, Epistula 22, 18.

28 Hieronymus, Epistula 22, 18. 
rozżarzone pociski Złego" (Ef 6,16). Zdanie pochodzi z tej części listu, w której apostoł wyjaśnia pojęcie i elementy duchowej walki, jaką toczy w swoim życiu każdy chrześcijanin, używając adekwatnych do tego tematu sformułowań jak np. „Przyobleczcie pełną zbroję Bożą” (Ef 6,11); „Nie toczymy bowiem walki przeciw krwi i ciału, lecz przeciw Zwierzchnościom" (Ef 6,12); „Dlatego przywdziejcie pełną zbroję Bożą” (Ef 6,13); „Stańcie więc [do walki]” (Ef 6,14); ,Weźcie też hełm zbawienia i miecz Ducha, to jest słowo Boże" (Ef 6,17) ${ }^{29}$.

Jest $\mathrm{w}$ tych tekstach św. Pawła także pewne nawiązanie do Starego Testamentu, w którym niekiedy przedstawiano Boga jako tego, który uzbrajał się przeciw swoim wrogom (por. Iz 11,4-5; Mdr 5,17-23). Paweł wykorzystuje te fragmenty jednak w innym kontekście, zaleca bowiem tę samą zbroję Bożą samemu chrześcijaninowi, który ma walczyć przeciwko „,żywiołom świata” (por. Ga 4,3), duchom niewiernym Bogu, które chcą poddać sobie człowieka w grzechu. Chrystus przyszedł, aby nas od nich uwolnić i tylko dzięki temu chrześcijanin może już stawić im czoła.

Św. Hieronimowi bardzo odpowiadają wspomniane teksty biblijne z racji na ich ciągłą aktualność, obrazowość i tradycję. Dlatego chętnie się nimi posługuje w swoim wykładzie kierowanym do Eustochium. Także dziewice są otoczone wieloma wrogami, którymi są przede wszystkim złe żądze, nałogi i przyzwyczajenia. Stanowią one w jakiejś mierze owoc działalności diabła, duchowego przeciwnika postępu dziewicy poświęconej Bogu. Dziewica toczy mocną walkę duchową i jest narażona na wiele niebezpieczeństw także z jeszcze innego powodu: wybrała ona formę życia doskonalszą i jednocześnie trudniejszą niż małżeństwo.

29 W cytowanych tekstach św. Pawła można dostrzec pewne zwroty nawiązujące do języka wojskowego. Zob. M. Wysocki, Pewniejsza nadzieja? Zachęty do życia monastycznego w epistolografii IV $i$ V wieku, VoxP 70 (2018) s. 193-204. Autor analizuje listy m.in. św. Hieronima, jak też św. Ambrożego, św. Augustyna i św. Paulina z Noli, w których dostrzega się wyraźną zachętę do podjęcia drogi życia monastycznego. W niektórych tekstach pojawia się wyraźnie idea miles Romae - miles Christi. „Najliczniejszą grupą, spośród odbiorców listów, do której kierowane były zachęty do życia monastycznego, byli żołnierze" (Wysocki, Pewniejsza nadzieja?, s. 194). 


\section{Duchowa walka w dziewictwie, które jest wyższe od małżeństwa}

Znaczna część Listu 22 poświęcona jest wyższości dziewictwa nad małżeństwem ${ }^{30}$, która zdaniem św. Hieronima jest ukazana już w Księdze Rodzaju:

Ewa była w raju dziewicą; małżeństwo pojawiło się po skórzanych tunikach. Twoją ojczyzną jest raj. Zachowaj to, gdzie się urodziłaś i mów: „Wróć, moja duszo, do swego spokoju" (Ps 116,7). Abyś zaś wiedziała, że dziewictwo należy do natury, a małżeństwo [nadeszło] po występku: ciało rodzi się z małżeństwa jako dziewicze, oddając w owocu to, co straciło w korzeniu ${ }^{31}$.

Zwrot ,po skórzanych tunikach”, po których pojawiło się małżeństwo, nabiera tutaj szczególnego znaczenia. Chodzi o nowy wymiar antropologiczny w odniesieniu do natury ludzkiej. Negatywne wydarzenie, jakie miało miejsce na początku dziejów ludzkości, zmieniło sytuację człowieka w odniesieniu do jego Stwórcy. Pierwsi rodzice, po sprzeniewierzeniu się woli Bożej i upadku, założyli skórzane tuniki ${ }^{32}$. Z tekstu wynika, że dziewictwo pojawiło się po grzechu Adama i Ewy ${ }^{33}$. Stąd wniosek, że dziewica należy, przynajmniej w jakiejś mierze, do tego stanu, który charakteryzo-

30 Zob. opracowanie monograficzne na ten temat: P. Nehring, Dlaczego dziewictwo jest lepsze niż matżeństwo? Spór o ideat $w$ chrześcijaństwie zachodnim końca IV $w$. w relacji Ambrożego, Hieronima i Augustyna, Toruń 2005. Autor studium przeprowadza wnikliwą analizę tematu, analizując odnośne teksty wymienionych autorów okresu patrystycznego. Zwraca uwagę przede wszystkim na obawę (metus) przed przykrościami, z jakimi wiązało się małżeństwo, z drugiej zaś na nadzieję (spes) na ich uniknięcie w przypadku wyboru dziewictwa. Warto zauważyć, że najobszerniejsza część pracy, zatytułowana Hieronim - apogeum kontrowersji (s. 81-191), została poświęcona właśnie naszemu pisarzowi. Autor opracowania ukazuje, że wymienieni egzegeci starali się dowieść, że dziewictwo góruje nad małżeństwem, które także jest dobrem, bo sprawniej prowadzi do jeszcze większego dobra, jakim jest świętość.

31 Hieronymus, Epistula 22, 19.

32 Zob. L. Mirri, Il matrimonio in san Girolamo, VoxP 30-31 (1996) s. 367-368: „Riferimento preciso di questa idea dominante è proprio quello delle «tuniche di pelle», indicante una nuova dimensione antropologica in relazione alla natura umana. Tale proposizione protologica, investendo la sfera ontologica, comporta l'affermazione di un evento negativo, in contraddizione col piano divino sull'essere umano ed avente per conseguenza la caduta e la cattività dell'anima in una qualità terrestre o animale del corpo".

33 Zob. L. Mirri, La teologia dello status monasticus in S. Girolamo, w: Il monachesimo occidentale dalle origini alla Regula Magistri, SEA 62, Roma 1998, s. 271-277. 
wał pierwszych rodziców przed ich upadkiem - „Twoją ojczyzną jest raj”. Podobnie ciało ludzkie w stanie narodzin ma charakter dziewiczy, który traci wtedy, kiedy dochodzi do związków cielesnych.

Zresztą na początku dziejów, gdy ludności było stosunkowo niewiele, istniało jedynie błogosławieństwo udzielane z powodu posiadania synów. Dlatego patriarchowie mieli za zadanie rozmnażać się, aby przysparzali czcicieli prawdziwego Boga. Jednak już w czasach Starego Testamentu, gdy świat zaczął się zaludniać, Bóg rozpoczął ukazywać wartość dziewictwa swoim wybranym mężom, wystarczy podać przykład Eliasza, Elizeusza i Jeremiasza:

Powoli jednak, podczas gdy wzrastał zasiew, został posłany żeńca. Dziewiczym był Eliasz, dziewiczym Elizeusz, dziewiczymi było wielu synów proroków. Do Jeremiasza mówi się: „Nie weźmiesz sobie żony” (Jr 16,2). Uświęcony w łonie [matki] - w czasie, gdy przybliża się niewola - otrzymuje zakaz ożenienia się ${ }^{34}$.

Św. Hieronim przywołuje w tekście najwyższe autorytety proroków Starego Testamentu i zwraca w tym miejscu uwagę nie tyle na ich nauczanie, ile na świadectwo życia, a zwłaszcza na dziewictwo. Wydaje się, że fundamentem tych słów św. Hieronima jest przekonanie, że przepowiadanie proroków łączy się z pewnym stylem zachowania obejmującym w tym wypadku bezżeństwo i szczególne poświęcenie się w swojej działalności jedynemu Bogu. To właśnie w ten sposób samo ich życie staje się widocznym i wyraźnym dla wszystkich znakiem potwierdzającym prawdziwość ich działalności. Pisząc o prorokach w taki sposób, św. Hieronim dołącza do tych autorów okresu patrystycznego, którzy ukazywali ich jako pewien wzór dla mnichów i ascetów. Jednak autor wyraźnie stwierdza, że nie zamierza krytykować małżeństwa jako takiego: „Powie ktoś: «Śmiesz oczerniać małżeństwo, które zostało pobłogosławione przez Pana?». Nie jest oczernianiem małżeństwa, gdy stawia się przed nimi dziewictwo. Nikt nie porównuje zła i dobra. Także i mężatki niech się szczycą, ponieważ są na drugim miejscu po dziewicach"35.

34 Hieronymus, Epistula 22, 21.

35 Hieronymus, Epistula 22, 19. Zob. J. Pochwat, Obraz Maryi u św. Hieronima w jego „Komentarzu do Ewangelii wedtug św. Mateusza”, VoxP 57 (2012) s. 505-519. Autor artykułu ukazuje Maryję u św. Hieronima jako tę, do której jako wzorca odnosić można zarówno dziewictwo, macierzyństwo, jak i małżeństwo. 
Już ta wstępna „obrona” małżeństwa wydaje się bardzo znacząca. W tekście wyraźnie się mówi, że dziewictwo jest przed małżeństwem (choć to ostanie jest pobłogosławione przez Pana) i że w konsekwencji mężatki zajmują w „hierarchii” duchowej drugie miejsce, właśnie po dziewicach. Św. Hieronim argumentuje swój pogląd ściśle teologicznie:

Niech kieruje się ku mężowi ta, która nie ma za oblubieńca Chrystusa! W końcu zaś: „Niechybnie umrzesz” (Rdz 2,17): taki kres małżeństwa! Mój zaś sposób życia nie jest związany z płcią. Niechaj małżeństwo ma swój czas i swoją świetność; dla mnie dziewictwo zostało uświęcone w Maryi i w Chrystusie ${ }^{36}$.

Rozumowanie św. Hieronima jest następujące: dziewictwo jest wyższe od małżeństwa, bo było zachowywane przez Jezusa i Jego Matkę. Jest zatem proponowane tym, którzy chcą prowadzić podobny styl życia. Kobieta, która wybiera męża, bierze właśnie jego za oblubieńca. Inaczej natomiast rzecz się ma w przypadku osoby zachowującej dziewictwo - ta wybiera jako oblubieńca Chrystusa.

W podobnym duchu św. Hieronim przeprowadza egzegezę znanego tekstu Mt 13,3-23, czyli przypowieści o siewcy odnoszonej przez niego właśnie do różnych stanów. Autor, pisząc do Eustochium, wspomina jej starszą siostrę, która została wdową w siódmym miesiącu po wyjściu za mąż:

Straciła zarówno wieniec dziewictwa jak i rozkosz małżeństwa! I chociaż zajmuje drugi stopień czystości, to jednak - jak sądzisz? - ile krzyży teraz musi znieść, widząc codziennie w siostrze to, co sama straciła $\mathrm{i}$ - chociaż jest trudniej jej wyzbyć się pożądliwości, gdyż jej doświadczyła - ma mniejszą zapłatę za wstrzemięźliwość? Niech jednak i ona będzie pewna, niechaj będzie radosna: stokrotny i sześćdziesięciokrotny owoc pochodzi z jednego nasienia czystości ${ }^{37}$.

Zdaniem św. Hieronima, tylko ten, kto żyje w stanie dziewiczym, wydaje plon stokrotny. W odróżnieniu jednak od wyżej przytoczonego tekstu tutaj św. Hieronim na drugim miejscu wymienia wdowy przynoszące plon sześćdziesięciokrotny. Mężatki są na ostatnim, trzecim miejscu i wydają

36 Hieronymus, Epistula 22, 18.

37 Hieronymus, Epistula 22, 15. 
plon trzydziestokrotny ${ }^{38}$. Należy w tym miejscu dodać, że tę samą przypowieść w podobny sposób wyjaśniał wcześniej św. Ambroży ${ }^{39}$, inaczej zaś interpretowali ją św. Cyprian z Kartaginy ${ }^{40} \mathrm{i}$ św. Augustyn ${ }^{41}$.

Nie mogło w tekstach św. Hieronima o dziewictwie i jego wyższości nad małżeństwem zabraknąć, pojawiającego się już wcześniej, wątku maryjnego. Pisarz zwraca $\mathrm{w}$ tym kontekście uwagę na odmienne postawy Ewy i Maryi:

Owo dobrodziejstwo wstrzemięźliwości widoczne było jedynie u mężczyzn, a Ewa ustawicznie rodziła w boleściach. Skoro jednak poczęła w łonie Dziewica i porodziła nam chłopca, na którego barkach spoczęła władza, Boga Mocnego, Ojca przyszłego wieku, odjęte zostało przekleństwo. Przez Ewę [przyszła] śmierć, przez Maryję - życie. Dlatego więc dar dziewictwa hojniej rozlał się na kobiety, gdyż rozpoczął się od Kobiety ${ }^{42}$.

Warto przede wszystkim zwrócić uwagę na pewną „chronologię” wydarzeń w pojmowaniu dziewictwa w całym procesie zbawczym. Najpierw zatem się mówi o wstrzemięźliwości jedynie u mężczyzn, jak to było widać we wcześniejszym tekście w odniesieniu do proroków Starego Testamentu. Ewa zaś i wszystkie inne matki wydawały w tym czasie na świat potomstwo w boleściach jako skutek przekleństwa. To zaś zostało z nich zdjęte dopiero w momencie poczęcia w łonie Maryi i narodzin Jezusa Chrystusa. Dlatego też św. Hieronim, idąc po linii niektórych swoich poprzedników, dochodzi do bardzo ważnego syntetycznego stwierdzenia: „Przez Ewę [przyszła] śmierć, przez Maryję - życie”. Od tego to momentu dar dziewictwa dotyczy bardziej kobiet, bo od Matki Najświętszej bierze, w jakiejś mierze, swój początek.

38 Św. Hieronim analizuje szerzej tę przypowieść w innych swoich dziełach. Zob. Hieronymus, Adversus Iovinianum I 3, 40 oraz II 19, 35. Pismo to jest poświęcone w znacznej mierze wyższości stanu dziewictwa nad małżeństwem.

39 Zob. Ambrosius, De virginibus I 10, 60.

40 Zob. Cyprianus, De habitu virginum 21.

41 Zob. Augustinus, De sancta virginitate 45.

42 Hieronymus, Epistula 22, 21. Warto w tym miejscu dodać, że stwierdzenie, wedle którego przez Ewę przyszła śmierć, a przez Maryję życie, pojawia się już u wcześniejszych pisarzy chrześcijańskich. Zob. Tertullianus, De carne Christi 17. Było też uwzględniane i rozwijane w następnych stuleciach i w różnych środowiskach teologicznych, jak wynika np. ze studium: M. Starowieyski, Maria nova Eva in traditione Alexandrina et Antiochena saec. V, „Marianum” 24 (1972) s. 339-349. 
Omawiając temat wyższości dziewictwa nad małżeństwem, św. Hieronim nie mógł pominąć znanego tekstu św. Pawła zjego Pierwszego Listu do Koryntian (7,32-34):

Człowiek bezżenny troszczy się o sprawy Pana, o to, jakby się przypodobać Bogu. Ten zaś, kto wstąpił w związek małżeński, zabiega o sprawy świata, o to, jak by się przypodobać żonie. I doznaje rozterki. Podobnie i kobieta: niezamężna i dziewica troszczy się o sprawy Pana, o to, by była święta ciałem, i duchem. Ta zaś, która wyszła za mąż, zabiega o sprawy świata, o to, jak by się przypodobać mężowi ${ }^{43}$.

Dla apostoła Pawła „sprawy Pana” są absolutnie na pierwszym miejscu i im trzeba bezwarunkowo podporządkować nasze siły fizyczne i duchowe. Co więcej, spełnienie tej misji wymaga niepodzielności tego, kto jest do jej spełnienia powołany ${ }^{44}$. Można byłoby dopatrywać się w tych słowach obecności filozofii stoickiej, która głosiła potrzebę całkowitej wolności wewnętrznej dla osiągnięcia wyznaczonego sobie celu życiowego. Jednak św. Paweł idzie w swoim myśleniu dalej aniżeli proponował wspomniany nurt filozoficzny. Jest tutaj bardzo wyraźne odniesienie się do Pana, do świętości i ciała, i ducha, czyli do tych elementów, które nie występowały u stoików.

Pisze następnie św. Hieronim o pewnej wolności od utrapień w przypadku dziewicy i powołuje się przy tym na wcześniejszych pisarzy. Wymienia bowiem z imienia Tertuliana i jego dzieło skierowane do przyjaciela filozofa ${ }^{45}$, oraz ,wspaniałą księgę błogosławionego Cypriana i utwory papieża Damazego na ten temat, oraz niedawno napisane dzieła naszego Ambrożego, które ułożył dla siostry. W nich to zabłysnął tak wielką wymową, iż przebadał, uporządkował, wyraził to wszystko, co dotyczy pochwały dziewic"46.

43 Zob. Hieronymus, Epistula 22, 21.

44 Zob. R. Penna, Prima Lettera ai Corinzi, w: Le Lettere di Paolo, red. T. Aurelio et al., Genova 1996, s. 70, przyp.: „Appare di qui che l'essere «senza preoccupazioni» (v. 32) o «senza distrazioni» (v. 35) non va grossolanamente confuso con una irresponsabile sottrazione agli impegni e alle difficoltà della vita, ma si identifica con una adesione incondizionata ad una superiore missione di servizio al Signore e ai fratelli, che richiede l'indivisibilità di chi vi è chiamato".

45 Por. Tertullianus, De exhortatione castitatis.

46 Hieronymus, Epistula 22, 22. Zob. Cyprianus, De habitu viriginum. Nie wydaje się, aby cokolwiek zachowało się do naszych czasów z pism Damazego w odniesieniu do omawianego tematu. 
Nie zaskakuje nas ta doskonała znajomość tradycji chrześcijańskiej w odniesieniu do dziewictwa. Św. Hieronim wyjątkowo dobrze się orientował w tym, co zostało napisane o dziewicach przez innych pisarzy. Nie dziwi też fakt, że chwali przede wszystkim św. Ambrożego ${ }^{47}$ za jego badania, za dzieło uporządkowania, za kompletny i systematyczny wykład tego tematu.

\section{Podsumowanie}

Jako że omawiany List 22 św. Hieronima stanowi traktat dotyczący życia monastycznego, ze szczególnym uwzględnieniem dziewictwa, wydają się logiczne w konkluzji pytania o aktualność poglądów świętego ze Strydonu i ich pożytek dla współczesnej dyskusji w tej dziedzinie i dla życia zakonnego.

Św. Hieronim przedstawia koncepcję życia zakonnego i dziewictwa, która ma wyraźnie charakter chrystologiczny. Kto umartwia swoje ciało, aby opanować pożądliwości, może w sposób spokojny pytać ze św. Pawłem: „Któż nas odłączy od miłości Chrystusowej?”. Syn Boży dał nam dowody, opisane i ukazane w wielu tekstach biblijnych, zwłaszcza u św. Pawła, wielkiej miłości, pokory, wyniszczenia samego siebie i poniżenia się dla nas. Wszystko to zobowiązuje uczniów Chrystusa do odpowiedzenia na taką postawę miłością, duchową walką i wyrzeczeniami.

Pisarz wskazuje także na potrzebę mocnego związku dziewic z całą wspólnotą Kościoła. Rozwijając aspekt eklezjalny życia monastycznego i dziewictwa, św. Hieronim zachęca wszystkich do trwania w prawowiernej nauce Kościoła i do pozostawania w głębokiej komunii z pozostałymi wierzącymi. Dziewictwo ma znaczenie, gdy przeżywane jest w Kościele i z niego czerpie wsparcie i pomoc.

Monastycyzm i dziewictwo ukazane przez św. Hieronima są zdecydowanie biblijne. Pisarz opiera się główne na Piśmie Świętym, zwracając uwagę na odnośne postaci, które prowadziły szczególny tryb życia, i przytaczając teksty motywujące sens tego typu życiowego wyboru. Wybrane teksty biblijne ukazują wyraźną potrzebę duchowych zmagań w życiu każdego chrześcijanina, a zwłaszcza tego, który otrzymuje i akceptuje szczególną formę powołania. Owe zmagania dotyczą w sposób szczególny sfery

47 Można przypuszczać, że chodzi tu przede wszystkim o dzieła biskupa Mediolanu zatytułowane De virginibus oraz De virginitate. Nieco później, już po tym jak św. Hieronim ukończył swój List 22, św. Ambroży wydał De institutione virignis i Exhortatio virginitatis. 
cielesnej człowieka. Można je pokonywać, współpracując z łaską Bożą, otwierając się na dary Boże, czytając i medytując słowa zawarte w Piśmie Świętym.

Takie ujęcie monastycyzmu chrześcijańskiego, ze zwróceniem szczególnej uwagi na temat dziewictwa, ale też z jednoczesnym ukazaniem potrzeby wyrzeczeń ze strony mniszki czy mnicha, podejmowanych dla Chrystusa i Jego Królestwa, odznacza się dużym optymizmem i wydaje się w wielu punktach aktualne także w naszych czasach. Pisarz wychwala radość poświęcenia się Bogu poprzez czystość i podejmowane duchowe walki, które sprawiają, że już w czasie życia ziemskiego zakonnik przeżywa szczególną relację z Jezusem Chrystusem. Jej pełnia nastąpi jednak dopiero po śmierci (aspekt eschatologiczny dziewictwa), zgodnie z tym co zapowiadają odnośne teksty Pisma Świętego, a zwłaszcza słowa samego Zbawiciela.

\title{
Virginity Interpreted as a Constant Struggle for the Lord: Biblical Foundations in St. Jerome's Letter 22 to Eustochium
}

(summary)

\begin{abstract}
St. Jerome deals with many themes in his Letter 22 to Eustochium, but the author focuses on virginity interpreted as a constant struggle for the Lord and he analyses the Biblical foundations of this exposition. He first tries to clarify St. Jerome's purpose as he wrote this letter, that is, the articulation, in the light of the Bible, on the one hand of the reason and beauty of life in virginity, and on the other hand the difficulties and renunciations that have to be constantly undertaken so as to persevere in this state. He then discusses the pertinent Biblical references, primarily from the New Testament and in particular from the Gospels and the letters of the apostle St. Paul. He analyses their use, the chosen expressions and terms (sometimes taken from the vocabulary of sportsmen and soldiers) and their literary and doctrinal context. He then lists concrete elements of the spiritual struggle undertaken by the virgin for Christ (prayer, meditating of the Sacred Scriptures, silence, fasting, remaining at home, various mortifications pertaining to the body and spirit), as the Lord has personally given us proofs of supreme love, poverty and perseverance in the withstanding of sufferings. Finally, in the context of the continuously actual debate about virginity and marriage, he questions the value of the discussed Letter 22 of St. Jerome for this theme within a Biblical, Christological, ecclesiological and eschatological perspective.
\end{abstract}

Keywords: virgin; virginity; chastity; marriage; struggle; body; soul; unmarried state; concupiscence; poverty; patience; suffering; renunciation; mortification; fasting; continence 


\title{
Dziewictwo rozumiane jako ustawiczna walka dla Pana. Fundamenty biblijne w Liście 22 św. Hieronima do Eustochium
}

\author{
(streszczenie)
}

Autor opracowania wybiera z wielu zagadnień poruszanych w Liście 22 św. Hieronima temat dziewictwa rozumianego jako ustawiczna walka dla Pana i analizuje fundamenty biblijne tej idei. Próbuje najpierw ustalić cel, jaki przyświecał św. Hieronimowi piszącemu ten list, czyli ukazanie w świetle Biblii z jednej strony racji i piękna życia w dziewictwie, $\mathrm{z}$ drugiej zaś trudów i wyrzeczeń, które trzeba nieustannie podejmować, aby wytrwać w tym stanie. Zajmuje się następnie odnośnymi tekstami biblijnymi pochodzącymi głównie z Nowego Testamentu, zwłaszcza z Ewangelii i z listów św. Pawła Apostoła. Analizuje ich użycie, wybrane zwroty i wyrażenia (pochodzące niekiedy ze świata sportowców i żołnierzy) oraz ich kontekst literacki i doktrynalny. Podaje następnie konkretne elementy duchowej walki podejmowanej przez dziewicę dla Chrystusa (modlitwa, rozważanie Pisma Świętego, milczenie, post, pozostawanie w domu, różne umartwienia dotyczące ciała i ducha), który osobiście dał nam dowody najwyższej miłości, ubóstwa i wytrwałości w znoszeniu cierpień. Pyta wreszcie na zakończenie, w kontekście ciągle aktualnej debaty dotyczącej dziewictwa i małżeństwa, o znaczenie omawianego Listu 22 św. Hieronima dla tego tematu w perspektywie biblijnej, chrystologicznej, eklezjologicznej i eschatologicznej.

Słowa kluczowe: dziewica; dziewictwo; czystość; małżeństwo; walka; ciało; dusza; bezżeństwo; pożądliwość; ubóstwo; cierpliwość; cierpienie; wyrzeczenie; umartwienie; post; wstrzemięźliwość

\section{Bibilografia}

\section{Źródła}

Ambrosius, De institutione virginis, ed. F. Gori, SAEMO 14/2, Milano 1989, s. 110-195, tł. W. Kania, Św. Ambroży, Na obłóczyny dziewicy, TMB 2, Niepokalanów 1981, s. $43-68$.

Ambrosius, De virginibus, ed. F. Gori, SAEMO 14/1, Milano 1989, s. 100-240, tł. W. Szołdrski - K. Obrycki, Św. Ambroży, O dziewicach, w: Św. Ambroży, Wybór pism, cz. 2, PSP 35, Warszawa 1986, s. 173-228.

Ambrosius, De virginitate, ed. F. Gori, SAEMO 14/2, Milano 1989, s. 11-107.

Ambrosius, Exhortatio virginitatis, ed. F. Gori, SAEMO 14/2, Milano 1989, s. 198-271. Augustinus, De sancta virginitate, ed. M. Palmieri, NBA 7/1, Roma 1978, s. 74-158, tł. P. Nehring, Św. Augustyn, O świętym dziewictwie, w: Św. Augustyn, Pisma monastyczne, ŹM 27, Kraków 2002, s. 271-348.

Cyprianus, De habitu virginum, ed. W. Hartel, CCL 3A, Turnhout 1976, s. 185-205, tł. J. Czuj, Św. Cyprian, O stroju dziewic, w: Św. Cyprian, Pisma, t. 1: Traktaty, POK 19, Poznań 1937, s. 135-156. 
Hieronymus, Epistula 22, ed. I. Hilberg, CSEL 54, Vindobonae - Lipsiae 1910, s. 143-211, tł. B. Degórski, Św. Hieronim, List 22, w: Św. Hieronim, Listy do Eustochium, ŹM 33, Kraków 2004, s. 111-190.

Hieronymus, Epistula 31, ed. I. Hilberg, CSEL 54, Vindobonae - Lipsiae 1910, s. 249-251, tł. B. Degórski, Św. Hieronim, List 31, w: Św. Hieronim, Listy do Eustochium, ŹM 33, Kraków 2004, s. 191-193.

Hieronymus, Epistula 108, ed. J.W. Smit, VS 4, s. 145-236, tł. B. Degórski, Św. Hieronim, List 108, w: Św. Hieronim, Listy do Eustochium, ŹM 33, Kraków 2004, s. $195-275$.

Hieronymus, Vita S. Pauli Primi Eremitae, ed. B. Degórski, Opere di Girolamo 15, Roma 2014, s. 72-115, tł. B. Degórski, Św. Hieronim, Żywot mnicha Pawła, w: Św. Hieronim, Żywoty mnichów, Pawła, Hilariona, Malchusa, ŹM 10, Kraków 1995, s. 85-112.

Hieronymus, Adversus Iovinianum, PL 23, 211-338, tł. L. Nieścior, Św. Hieronim ze Strydonu, Przeciw Jowinianowi, w: Św. Hieronim ze Strydonu, Pisma polemiczne. Przeciw Helwidiuszowi, Przeciw Jowinianowi, Przeciw Wigilancjuszowi, ŹM 67, Kraków 2013, s. 115-384.

Tertullianus, De carne Christi, ed. J.P. Mahé, SCh 216 i 217, Paris 1975.

Tertullianus, De exhortatione castitatis, ed. W. Munier, SCh 319, Paris 1985, tł. K. Obrycki, Tertulian, Napomnienie o czystości, w: Tertulian, Wybór pism, t. 2, PSP 29, Warszawa 1983, s. 165-181.

\section{Opracowania}

Adkin N., Jerome on virginity. A Commentary on the Libellus de viriginitate servanda (Letter 22), Classical and Medieval Texts. Papers and Monographs 42, Cambridge 2003.

Bandura A., Athleta Christi nella patristica latina dei primi quattro secoli, Roma 1994.

Degórski B., L'insegnamento monastico Geronimiano, VoxP 32-33 (1997) s. 199-214.

Degórski B., Wstęp, w: Św. Hieronim, Listy do Eustochium, ŹM 33, Kraków 2004, s. 11-88.

Degórski B., Bibliografia, w: Św. Hieronim, Listy do Eustochium, ŹM 33, Kraków 2004, s. 89-108.

Gribomont J., Eustochio, NDPAC I 1866-1867.

Kochel J., Nauka o czystości i dziewictwie w Listach św. Hieronima, w: J. Kochel, Wychowanie do czystości - utopia czy zadanie, Człowiek - Rodzina - Społeczeństwo 20, Opole 2011, s. 21-35.

Mirri L., Donna e verginità nei Padri (Girolamo e Ambrogio), „Studi Francescani” 88 (1991) s. 339-362.

Mirri L., La vita ascetica femminile in san Girolamo, Roma 1992.

Mirri L., Il matrimonio in san Girolamo, VoxP 30-31 (1996) s. 365-378.

Mirri L., La dolcezza nella lotta. Donne e ascesi secondo Girolamo, Spiritualità occidentale, Magnano 1996. 
Mirri L., La teologia dello status monasticus in S. Girolamo, w: Il monachesimo occidentale dalle origini alla Regula Magistri, SEA 62, Roma 1998, s. 271-277.

Nehring P., Dlaczego dziewictwojest lepsze niż matżeństwo? Spóro ideał wchrześcijaństwie zachodnim końca IV w. w relacji Ambrożego, Hieronima i Augustyna, Torun 2005.

Penna R., Prima Lettera ai Corinzi, w: Le Lettere di Paolo, red. T. Aurelio et al., Genova 1996, s. 53-93.

Pochwat J., Obraz Maryi uśw. Hieronima w jego „, Komentarzu do Ewangelii wedtug św. Mateusza”, VoxP 57 (2012) s. 505-519.

Potterie de la I., Dziewictwo, w: Stownik Teologii Biblijnej, red. X. Léon-Dufour, tł. K. Romaniuk, Poznań - Warszawa 1982, s. 253-256.

Starowieyski M., Hieronim ze Strydonu, NSWP, s. 436-447.

Starowieyski M., Maria nova Eva in traditione Alexandrina et Antiochena saec. $V$, „Marianum" 24 (1972) s. 339-349.

Steininger C., Die ideale christliche Frau: virgo - vidua - nupta. Eine Studie zum Bild der idealen christlichen Frau bei Hieronymus und Pelagiusz, St. Ottilien 1997.

Wysocki M., Pewniejsza nadzieja? Zachęty do życia monastycznego $w$ epistolografii IV $i$ V wieku, VoxP 70 (2018) s. 193-204. 